\title{
Socio-economic and Institutional Factors Limiting Adoption of Wheat Row Planting in Selected Districts of Arsi Zone
}

\author{
Tolesa Alemu \\ Ethiopian Institute of Agricultural Research, Kulumsa Agricultural Research Center, P.O. Box: 489, Asella, \\ Ethiopia
}

\begin{tabular}{|c|c|}
\hline & \\
\hline \multirow{3}{*}{$\begin{array}{l}\text { Wheat yield is low in Ethiopia. Adoption of wheat row planting is one of the farming practices } \\
\text { believed to enhance wheat yield in the country. However, there are several socioeconomic and } \\
\text { institutional factors that limit adoption of wheat row planting. This study identifies the factors } \\
\text { that influence adoption of wheat row planting. Cross-sectional data collected from randomly } \\
\text { selected } 381 \text { farm households and logit model were used to achieve the objective of the study. } \\
\text { The study identifies that access to improved seed, agricultural extension services, education, } \\
\text { and livestock size positively and significantly affected adoption of wheat row planting. } \\
\text { Agricultural extension offices need to give due attention to household's access to improved } \\
\text { wheat seed and extension services for improving adoption of wheat row planting and thereby } \\
\text { increase wheat yield. Successful adoption and scaling up of wheat row planting also needs } \\
\text { improvement in household's educational status and livestock holding sizes. }\end{array}$} & $\begin{array}{l} \\
15 \\
15 \\
15\end{array}$ \\
\hline & \\
\hline & \\
\hline
\end{tabular}

\section{INTRODUCTION}

Wheat is one of the major food and cash crops for smallholders in Ethiopia. It is important cereal crop with annual production of about 3.43 million tons cultivated on an area of 1.63 million hectares (CSA, 2013). According to the CSA data, it occupies about 17 percent of the total cereal area in the country. However, its national average yield is about 21 quintals per hectare. This is low yield compared to global average of 40 quintals per hectare (FAO, 2009). The low yield has made Ethiopia unable to meet the high demand and the country is net importer of wheat (Rashid, 2010). The demand for wheat has been increased due to growing population, urbanization and the expansion of food processing industries in the country. If the country is to feed the rapidly growing population and meet the high demand, it needs to increase the production and yield of wheat. However, increasing yield requires successful adoption of improved agricultural technologies (Dorosh and Rashid, 2013).

One of the technologies is planting method (agronomic practice) for increasing yield. Adoption of row planting by smallholders is considered one of the farming practices for improving wheat yield in the country. The conventional planting method that is broadcasting seed by hand reduce yield because uneven distribution of the seeds makes hand weeding and hoeing difficult, and plant competition with weeds lowers wheat growth and tillering. This causes wheat yield reduction. However, row planting with proper distance between rows and plant density allows for sufficient aeration, moisture, sunlight and nutrient availability leading to proper root system development. Because of this, promotion and scaling-up of wheat row planting has been carried out in the selected study area by agricultural extension offices for several years. Though its impact linked to problems in implementation of the program and its recommendations, methodological issues, and over optimism of the potential of row planting in real farm setting (Vandercasteelen et al., 2013), the planting technique is seen as best agronomic practice by agricultural policy makers and extension personnel. The row planting has significant yield effect in midland and highland areas, but it has no significant yield effect in lowland agro-ecology (Tolesa et al., 2014). Though the row planting has significant effect on yield, there is limited empirical study in the study area that identifies socioeconomic and institutional factors influencing smallholders' adoption of wheat row planting. Therefore, this study attempted to identify socioeconomic and institutional factors limiting adoption of wheat row planting. The result of the study helps agricultural extension offices to successfully promote and scale up wheat row planting for improving wheat yield in the country.

\section{MATERIALS AND METHODS}

\section{The study Area}

The study area, Arsi Zone, is found in the central part of Oromia National Regional State of Ethiopia. According to Oromia Regional State Bureau of Finance and Economic Development report of 2010, the zone astronomically lies between $7^{0} 08^{\prime} 58^{\prime \prime} \mathrm{N}$ to $8^{0} 49^{\prime} 00^{\prime \prime} \mathrm{N}$ latitude and $38^{\circ} 41^{\prime} 55^{\prime \prime} \mathrm{E}$ to $40^{\circ} 43^{\prime} 56^{\prime \prime} \mathrm{E}$ longitude. The area is divided into five agro-climatic zones mainly due to variation in altitude. It is dominantly characterized by 
moderately cool (about 40 percent) followed by cool (about 34 percent) annual temperature. The mean annual temperature of the Zone is found between $20-25^{\circ} \mathrm{c}$ in the lowland and $10-15^{\circ} \mathrm{c}$ in the central highland.

The mean annual temperature of the zone is found between $20-25^{\circ} \mathrm{C}$ in the lowland and $10-15^{\circ} \mathrm{C}$ in the central highland. About 74 percent of zonal land area falls in moderately cool to cool temperature within the altitude range of 1,500 to 3,200 meters above sea level. On average, the zone gets a monthly mean rainfall of $85 \mathrm{~mm}$ and an annual mean rainfall of $1020 \mathrm{~mm}$. The area receives well distributed rainfall both in amount and season. This characteristics makes the zone good potential for production of various agricultural crops. Wheat is a major crop and it accounts for $42 \%$ of the total cereal area cultivated in the zone, with total output of 5.12 million quintals from 0.21 million hectares of cultivated land (CSA, 2013).

\section{Sampling Technique}

A combination of purposive sampling and three stages probability sampling procedures were used for sample selection. In the first case, Arsi zone which is a major wheat producing zone was purposively selected. The main reason for purposive selection was due to its representativeness in wheat production both in regional and national perspectives. There are also strong research and extension intervention programs embracing wheat producers in the zone. Moreover, newly released improved wheat varieties and improved farming practices were relatively more disseminated and practiced in this zone. Therefore, it was feasible to assess factors that influence adoption of wheat row planting in this zone. In the first stage of probability sampling, a list of major wheat producing districts within the zone was made. Then three districts were randomly selected by simple random sampling technique. The randomly selected districts were, namely, Lemu-Bilbilo, Hetosa, and Dodota.

In the second stage of the probability sampling, a list of major wheat growing lower administrative divisions (kebeles) within the selected districts was prepared. Then, two kebeles were selected from each district with simple random sampling. In the third and final stage, a list of wheat households was prepared for each selected kebeles. Sample households were selected by simple random sampling technique. The sample size was determined based on the formula given by Krejice and Morgan (1970), and allocation of sample size to each district and kebele was made proportionate to the size of wheat households of each district.

\section{Data Collection}

The data for study was collected from both primary and secondary sources. Cross-sectional data were collected from randomly selected sample farm households. Specifically designed and pre-tested questionnaire and trained data enumerators were used for the primary data collection. Both quantitative and qualitative data were collected. The data collection included households' demographic and socioeconomic characteristics (household sizes, age and sex structures, education, etc), land holding (agricultural, grazing, wheat land, and others), farm inputs utilization (seeds, fertilizers, herbicides and fungicides, labor utilization, credit, extension services), farm outputs, input and output prices, agronomic practices including crop rotation, wheat row planting and its inputs and output, and hand weeding, etc. Secondary information on rainfall amounts (annual mean and cropping season), temperature, etc were also collected. Data collection was carried out in 2013.

\section{Analytical Methods}

There are several tools that can be used in the analysis of farm technology adoption. They include frequency tables, contingency tables, correlation analysis, linear regression, and binomial choice models. The use of tables helps to compare adopters and non adopters of technologies. The use of binomial choice models involves qualitative response or regressand variable. In this study, the qualitative regressand variable was the adoption of wheat row planting. There are various approaches for the study of qualitative response models. The common ones are the linear probability models, logit model, probit model, and the tobit model (Gujarati, 2004; Greene, 2012). In these models, the dependent variable takes on values which are dummy in nature such as adopting a practice or not adopting the practice. Therefore, in models where the dependent variable is qualitative, the objective is to find the probability of something happening, such as adoption of wheat row planting. Hence, qualitative response regression models are often called probability models (Maddala, 1992; Gujarati, 2004).

The model with probability that lie between 0 and 1 , and varies nonlinearly with $\mathrm{X}$ variable is sigmoid or $\mathrm{S}$ shaped curve that resembles the cumulative distribution function of a random variable (Gujarati, 2004; Greene, 2012). The cumulative distribution functions that represent the 0 and 1 response model are the logistic and the normal that give rise to logit and probit models, respectively. The two models differ in the specification of the distribution of the error term, and in most cases the models are similar except the logistic distribution (the logit) has flatter tails (Maddala, 1992). The two models will produce similar results if the distributions of the sample values of $Y_{i}$ not too extreme. However, a sample in which the proportion $Y_{i}=1$ (or the proportion $Y_{i}=0$ ) is very small will be sensitive to the choice of cumulative distribution function. The estimation of the parameters of these non linear models is by using the technique of maximum likelihood (Greene, 2012). Empirical evidence suggests that neither Logit nor Probit have superiority over the other. The choice becomes a matter of preference (Gujarati, 2004). Therefore, the logit model was used for this study because of its computational and mathematical conveniences.

Based on Gujirati (2004), the logit model can be specified as follows:

If $P_{i}$ is the probability of adopting planting wheat in-row and $X_{i}$ is the socioeconomic factor influencing the adoption:

$$
\mathrm{P}_{\mathrm{i}}=\mathrm{E}\left(Y=1 \mid X_{i}\right)=\beta_{1}+\beta_{2} X_{i}
$$

Equation (1) can be represented as:

$$
\mathrm{P}_{\mathrm{i}}=\mathrm{E}\left(Y=1 \mid X_{i}\right)=\frac{1}{1+e^{-\left(\beta_{1}+\beta_{2 X_{i}}\right)}}
$$

If $Z_{i}$ is equal to $\beta_{1}+\beta_{2} X_{i}$, equation (2) can be written as:

$\mathrm{P}_{\mathrm{i}}=\frac{1}{1+e^{-Z i}}=\frac{e^{Z}}{1+e^{Z}}$, and this represents logistic distribution function. (3) 
If $P_{i}$ is the probability of adopting wheat row planting then $\left(1-P_{i}\right)$ is the probability of not adopting the row planting which is:

$$
1-\mathrm{P}_{\mathrm{i}}=\frac{1}{1+e^{Z i}}
$$

Therefore, $\frac{P_{i}}{1-P_{i}}=\frac{1+e^{Z_{i}}}{1+e^{-Z_{i}}}=e^{Z_{i}} \quad$ is odds ratio in favor of adopting the practice. (5)

Taking the natural logarithm of equation (5), gives

$$
\mathrm{L}_{\mathrm{i}}=\ln \left(\frac{P_{i}}{1-P_{i}}\right)=Z_{i}=\beta_{1}+\beta_{2} X_{i}
$$

Table 1: Descriptions, measurement and hypotheses of independent variables

\begin{tabular}{lllc}
\hline Variables & Measurement & Descriptions & Hypothesis \\
\hline Age & Years & Age of household head & - \\
Education & Grades & Educational level of household in level completed & + \\
Experience & Years & Farming experience of household head \\
Land & Hectares & Total land owned & + \\
Household size & Adult equivalent & Household members involved in farming & + \\
Livestock & TLU & Livestock holding size in tropical livestock unit (TLU) & + \\
Crops & Number & Number of different types of crops cultivated & + \\
Off-farm income & ETB & Household annual off-farm income in thousands ETB & $+/-$ \\
Fertilizers & Yes/No & Households use of chemical fertilizers, 1 if yes 0 otherwise & $+/-$ \\
Seed & Yes/No & Access and use of improved seed, 1 if yes and 0 otherwise & $+/-$ \\
Extension & Yes/No & Getting agricultural extension on planting wheat in row, 1 if yes, & + \\
Credit & Yes/No & and 0 otherwise & + \\
Agro-ecological & low/mid/ & Household access and use of credit service, 1 if yes 0 otherwise & $+/-$ \\
location & highland & Household agro-ecological setting, 1 if its agro-ecology and 0 for & $+/-$ \\
\hline
\end{tabular}

Where $L$ is the log of the odds ratio and it is called the logit. To estimate the logit model, equation (6) can be written as:

$\mathrm{L}_{\mathrm{i}}=\ln \left(\frac{P_{i}}{1-P_{i}}\right)=\beta_{1}+\beta_{2} X_{i}+u_{i}$, where $u_{i}$ is stochastic error term. (7)

The variables that were used in the model included the dependent variable (adoption of wheat row planting which assumed values of 0 and 1 ). A household was considered adopter if it used planting wheat in-row in 2012/13 cropping season. The independent variables that were assumed to affect adoption of wheat row planting were age and educational level of household head, farming experience, total land owned, household size, livestock holding size, total number of different types crops cultivated in 2012/13 cropping season, off-farm income, access to improved seed and credit services, access to chemical fertilizers and agricultural extension services, and household agro-ecological location (Table 2). The data were analyzed using STATA version 11 computer software program.

\section{RESULTS AND DISCUSSION}

\section{Descriptive Results}

The percentage of sample households adopted wheat row planting was 41 percent, 19.5 percent, and 40 percent in Dodota, Hetosa and Lemu-Bilbilo districts, respectively. From the total sample size, adopters of wheat row planting comprised 33.1 percent and the rest $(66.9$ percent) used broadcast planting method in the 2012/13 cropping season (Table 2). This implies that considerable percentage of households adopted planting wheat in-row in each selected district.
Table 2: Percentage of sample households adopted wheat row planting

\begin{tabular}{cccccc}
\hline Method of & \multicolumn{3}{c}{ Name of district } & \multirow{2}{*}{ potal } \\
\cline { 2 - 5 } planting & Dodota & Hetosa & Lemu-Bilbilo & \\
\multirow{2}{*}{ Broadcast } & $\mathrm{n}$ & 49 & 107 & 99 & 255 \\
& $\%$ & 59.0 & 80.5 & 60.0 & 66.9 \\
\hline \multirow{2}{*}{ In-row } & $\mathrm{n}$ & 34 & 26 & 66 & 126 \\
& $\%$ & 41.0 & 19.5 & 40.0 & 33.1 \\
\hline
\end{tabular}

Table 3 displays average yield of planting wheat in-row and broadcast. Yield of planting wheat in-row was higher than broadcast planting method in all study areas. The yield gain due to row planting in Dodota, Hetosa and Lemu-Bilbilo districts was about 11, 37 and 19 percents, respectively. The total average yield advantage due to row planting was 12.5 percent. The significance of the difference between the mean yields of the two methods of wheat planting was judged through analysis of variance (AVOVA). Wheat mean yield of row and broadcast planting methods was significantly different at $1 \%$ level of significance for the whole study area.

Table 3: Average yield per hectare for wheat planting

\begin{tabular}{|c|c|c|c|c|}
\hline \multirow{2}{*}{$\begin{array}{l}\text { Method of } \\
\text { plantings }\end{array}$} & \multicolumn{3}{|c|}{ Study areas } & \multirow[b]{2}{*}{ Total } \\
\hline & Dodota & Hetosa & $\begin{array}{l}\text { Lemu- } \\
\text { Bilbilo }\end{array}$ & \\
\hline Broadcast & 15.7 & 30.1 & 23.4 & 24.7 \\
\hline In-row & 17.4 & 41.2 & 27.9 & 27.8 \\
\hline $\begin{array}{l}\text { Average yield } \\
\text { gain }(\%)\end{array}$ & 10.8 & 36.8 & 19.2 & 12.5 \\
\hline
\end{tabular}
methods, in quintals

However, when the mean yield variance was analyzed for each district separately, Dodota district showed nonsignificance of yield difference at $1 \%$ significance level between the two methods of plantings. The mean yield difference between row and broadcast planting of wheat in Hetosa and Lemu-Bilbilo districts were significant. 


\section{Tolesa Alemu}

However, placing wheat seed in-row alone might not be a factor for yield advantage over broadcast planting method. Further comparative studies related to agronomic and plant management practices are needed. Agroecologically appropriate improved seed and fertilizers combined with the planting techniques are required to see the full effect of row planting. Because wheat yield is mainly affected by the use of appropriate input levels, agronomic and management practices.

\section{Econometric Estimation Results}

Descriptions and the measurements of variables used in the logit model are given in Table 1. During logit estimation, STATA automatically checks for collinear variables; and there were no collinear variables. The result after the fourth iteration is shown in Table 4. The Wald test was also conducted for testing the null hypothesis of logit model coefficients that all of the coefficients except the intercept are simultaneously equal to zero. The resulting chi-square test with 14 degrees of freedom $\left(\mathrm{chi}^{2}(14)=40.70\right.$, prob $\left.>\mathrm{chi}^{2}=0.0002\right)$ is greater than the $z$-value in the output from the estimation. This implies that the null hypothesis of all coefficients are simultaneously equal to zero is rejected at 0.01 leve $\left(\mathrm{chi}^{2}=40.7, \mathrm{df}=14, P<0.01\right)$. The likelihood-ratio test (LR $\mathrm{chi}^{2}(14)=56.74$, prob $>$ chi2 $=0.0000$ ) shows significant chi-squared statistic. The measure of fitness indicated by Pseudo or McFadden's $R^{2}$ is 0.11 . The goodness of fit is of secondary importance because what matters in logit model is the sign and statistical significance of the coefficients of explanatory variables. The z-test which is equal to the estimate divided by its standard error with two tailed significance level listed as $P>z$. The result depicts that having different educational level and livestock holding sizes had significant effects on the probability of adopting planting wheat in-row $(z=3.05, P<0.01$; and $z=$ 1.97, $P<0.05$ respectively). Similarly, having access to improved seed and agricultural extension services had significant effects on the probability of planting wheat inrow $(z=2.75, p<0.01$; and $z=3.12, P<0.01$ respectively). Livestock is source of farm manures and traction power as well as source of cash income for purchase of different farm inputs, and it enhances adoption of technology.

The coefficients of access to improved seed and extension service were tested whether they were equal in effect using wald test. The test statistic of equality of coefficients $\left(x^{2}(1)=3.06\right.$, prob $\left.>x^{2}=0.08\right)$ was not significant at 0.05 level; and the null hypothesis of equal effect of coefficients cannot be rejected. Therefore, the two variables had equal effect on the probability of adoption of planting wheat in-row. Therefore, variables education, access to improved seed and agricultural extension service and livestock holding size are statistically different from zero at 0.05 level; and they are significant variables that affect adoption of planting wheat in row. The estimated slope coefficients of the independent variables also suggest that for a unit increase in the independent variable, the log of the odds in favor of adopting row planting increases by the units equal to the value of the coefficient of the variable.

The effects of the coefficient on probability of adoption of row planting have been in line with the hypothesized effects of variables specified in Table 1 for each variable. As specified in the table, educated farmers are better able to process information and test the row planting method; livestock is a source of traction power in plowing and ease the labor constraint in row planting; improved seed is basic input for practicing row planting since farmers do not use local varieties; and agricultural extension service enables farmers to understand the usefulness of the row planting. Therefore, these variables increased household's probability of participation in wheat row planting.

Table 4: Determinants of adoption of wheat row planting

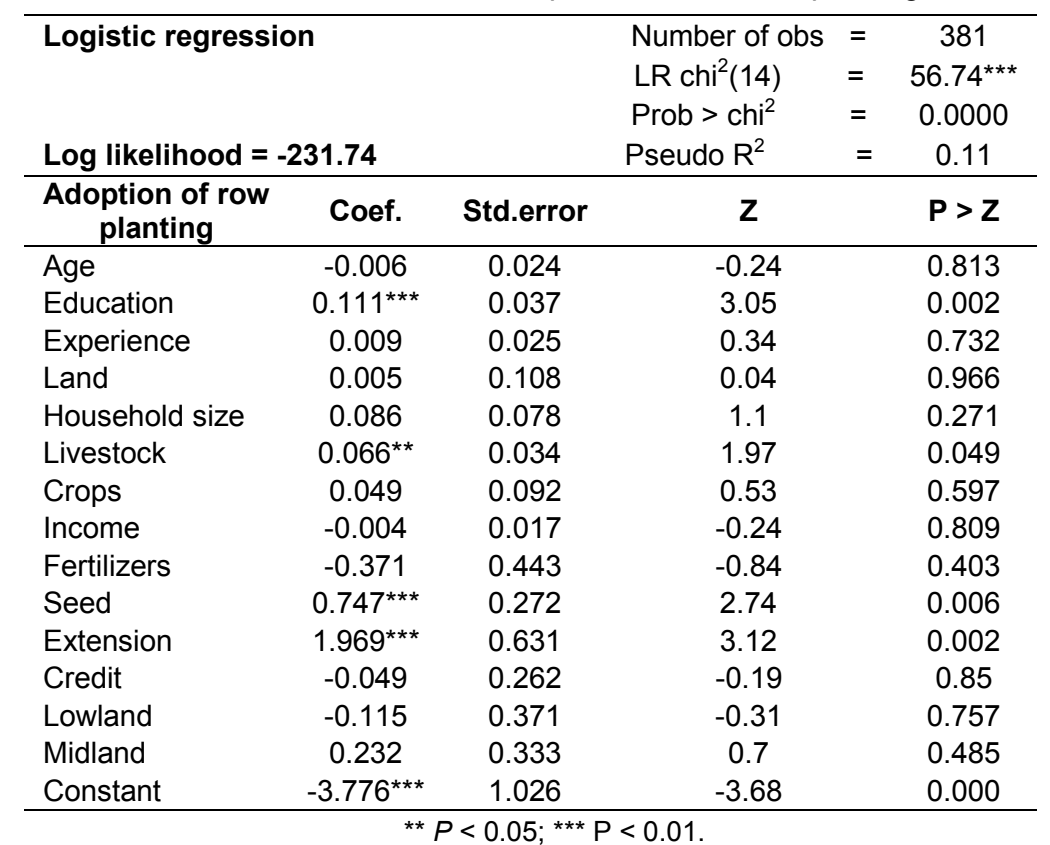

The sign of the coefficients are also the sign of the marginal effects for the logit model, indicating that the marginal effects of variables with positive significant influences on the probability of adopting planting wheat in row are also positive. Similarly, the marginal effects of age, off-farm income, access to credit and chemical fertilizers, and locations of household on the probability of adopting wheat row plating were negative but non- 
significant. The constant (intercept) is the value of the logodds in favor of row planting if the values of independent variables are zero. However, this has no physical meaning.

The linear combination of $X_{j} \beta$ was calculated to predict probability in the logit model, where $X_{j}$ are the independent variables in the $j^{\text {th }}$ observation and $\beta$ is the estimated parameter vector. Table 5 shows the predicted probability in the logit model for the adoption of planting wheat in-row. The prediction of probability of the positive outcome, that is, $\operatorname{Pr}$ (row planting = 1) in the logit model and its summary statistics show that the predicted probabilities in the sample range from 0.019 to 0.942 , with average probability of 0.428 . The mean probability of observing adoption of planting wheat in-row was 0.428 (Table 5). That is, the computed mean probability at the mean values of independent variables was 0.428 , indicating that the probability of a household adopting row planting was about 43 percent.

Table 5: Predicted probability for adoption of wheat row planting

\begin{tabular}{cccccc}
\hline Variable & Obs & Mean & Std. Dev. & Minimum & Maximum \\
\hline $\operatorname{Pr}($ row planting = 1) & 381 & 0.428 & 0.182 & 0.019 & 0.942 \\
\hline
\end{tabular}

\section{CONCLUSION}

Low use or lack of improved farm technologies is one of the major challenges facing wheat production in Ethiopia. Low utilization of farm inputs and adoption of improved farming techniques made yield of wheat low. The low yield, in turn, made the country unable to meet the high demand, and the country is net importer of wheat despite its good potential for wheat production. To feed the rapidly growing population and meet the high demand, smallholders need to increase wheat yield through adoption of improved agricultural technologies.

Wheat row planting is one of agronomic practices believed to increase wheat yield in Ethiopia. The agricultural extension offices have been promoting and scaling up the planting technique. As a result, wheat row planting has been practiced in various wheat producing regions of the country. However, there is limited empirical knowledge on the determinant factors for adoption of the row planting technique by farm households. To fill this gap, this study was carried out in major wheat producing zone of the country to identify the factors affecting the adoption of wheat row planting. Cross-sectional data were collected from randomly selected 381 farm households and logit model was used to achieve the objective of the study. The study identified that access to improved seed and agricultural extension services, educational level of household head, and livestock holding size were the factors that positively and significantly influenced adoption of wheat row planting. Agricultural extension offices need to give due attention to household's access to improved wheat seed and extension services for improving or increasing adoption of wheat row planting. Successful adoption and scaling up of wheat row planting also needs improvement in household's educational status and livestock holding sizes.

\section{Conflict of Interest}

Conflict of Interest none declared

\section{REFERENCES}

CSA (Central Statistical Agency of Ethiopia). (2013). Report on area and production of major crops, private peasant holdings, meher season, Addis Ababa.
Dorosh, P., and S. Rashid. (2013). Food and Agriculture in Ethiopia: Progress and Policy Challenges. University of Pennsylvania Press. Philadelphia, USA.

FAO (Food and Agriculture Organization of the United Nations), (2009). How to feed the world in 2050. (www.fao.org/fileadmin/templates/wsfs/docs/exp ertpaper/Howto Feed the World in 2050) Accessed November 12, 2012.

Greene, W.H.( 2012). Econometric analysis $7^{\text {th }}$ edition. USA, Pearson education, Inc.

Gujarati, D.N. (2004). Basic econometrics $4^{\text {th }}$ edition. India, New Delhi, Tata McGraw-Hill publishing company.

Krejcie, R.V. and Morgan, D.W. (1970). Determing sample size for research activities. Educational and Psychological Measurement 30: 607-610.

Lauren, N.K., Gallandt, E.R. and Mallory, E.B. (2012). Impact of spring wheat planting density, row spacing, and mechanical weed control on yield, grain protein, and economic return in Maine. Weed Science 60: 244 -253 .

Maddala, G.S. (1992). Introduction to Econometrics $2^{\text {nd }}$ edition. NewYork, Macmillan publishing company

Rashid, S. (2010). Staple Food Prices in Ethiopia. A paper prepared for the COMESA policy seminar on "Variation in staple food prices: Causes, consequence, and policy options, Maputo, Mozambique, 25-26 January 2010, under the African Agricultural Marketing Project (AAMP)

Tolesa Alemu., Bezabih Emana., Jema Haji and Belaineh Legesse. (2014). Impact of Wheat Row Planting on Yield of Smallholders in Selected Highland and Lowland Areas of Ethiopia. International Journal of Agriculture and Forestry 4(5): 386-393.

Vandercasteenlen, J., Mekdim D., Mintlen B. and Alemayehu S. (2013). The impact of the promotion of row planting on farmers' teff yields in Ethiopia. Ethiopia Strategy Support Program II, ESSP research note 27. International Food Policy Research Institute. 